\title{
REALITAS SOSIAL MASYARAKAT PERKAMPUNGAN DALAM NASKAH DRAMA H.A.H KARYA PUTU WIJAYA
}

\author{
Ferdian Achsani \\ dwikurniawan219@gmail.com \\ IAIN Surakarta
}

\begin{abstract}
The drama script is a type of prose fiction literature that can not only be enjoyed through pen strokes from writers, but also aims to be performed on stage shows. In drama scripts, the topic or story that is displayed is inseparable from the life of society in general. Through the action of the cast of the cast, it is able to show that the story brought in the script seems to reflect the real life. This study aims to describe the form of reality of social life that occurs in the H.A.H drama by Putu Wijaya. This research is in the form of qualitative descriptive, with the method of analysis analysis through the sociological approach of literature. The source of the data in this study is citation text in the H.A.H drama script by Putu Wijaya, which reflects the reality of social life in the village community. Data collection techniques in this study are document techniques. While the data validity technique used in this study uses source triangulation. Triangulangi source is one of the validity test data that is suitable for use in this study. After analysis, the results of this study show that Putu Wijaya's H.A.H drama script reflects the social life of the community such as: moral degradation, cultural shifts, social conflict, crime. This is due to weak economic conditions, lack of understanding of religious teachings about faith, faith and piety, and lack of education.
\end{abstract}

Keywords: sociology of literature, drama scripts, social reality

\section{PENDAhULUAN}

Putu Wijaya merupakan salah satu sastrawan yang tidak lagi diragukan karya-karyanya. Selain sebagai seorang sastrawan beliau juga menjadi seorang wartawan, penulis resensi buku dan film, juga pemimpin teater Mandiri. Karya-karya yang diciptakannya merupakan cerminan realita kehidupan masyarakat, yang tidak hanya terkenal di Indonesia, namun karya-karya beliau juga diterjemahkan dalam bahasa Arab, Thailand Spanyol dll.

Dari beberapa karya yang pernah beliau ciptakan, naskah drama H.A.H karya Putu Wijaya merupakan salah satu karya sastra yang menggambarkan kehidupan masyarakat sekaligus memberikan pengajaran moral. Dikatakan sebagai gambaran masyarakat saat ini karena dalam naskah ini menceritakan perjuangan hidup masyarakat yang tinggal di daerah perkampungan yang miskin dan jauh dari kehidupan yang diidealkan. Naskah drama ini juga bercerita bagaimana kehidupan para tetangga yang begitu benci dengan keluarga Bopeng, namun ketika mengetahui bahwa Bopeng mendapatkan lotre satu miliyar, para tetangga berbondong-bondong meminta sumbangan kepadanya.Selain sebagai bentuk tiruan dari masyarakat perkampungan yang serba krisis, dalam naskah ini juga berisi amanat yang mendalam sekaligus bentuk kritikkan yang ingin disampaikan oleh Putu Wijaya. Naskah drama ini menceritakan perjalanan kehidupan Warni, yang setiap hari selalu mendapatkan konflik dengan para tetangga, nenek, Pincang, Bopeng (suaminya) hingga dengan anakanaknya. Dalam menghadapi permasalahan yang terus datang, membuat Warni kewalahan dan akhirnya nekat untuk gantung diri. 
Tiuran yang terjadi dalam naskah drama tersebut merupakan bentuk konflik yang sering terjadi belakangan ini. naskah drama ini seakan menjadi rangkuman dari peristiwa-peristiwa yang terjadi di masyarakat, meskipun naskah drama ini sudah beberapa tahun lamanya ditulis oleh Putu Wijaya.

Putu Wijaya patut diacungi jempol, atas kepiawaiannya dalam menggambarkan kehidupan masyarakat dalam naskah drama ini. Karya-karya drama Putu Wijaya tak jarang selalu mengangkat kehidupan yang keras getir yang di dalamnya terdapat pesan ataupun amanat yang mendalam yang ditujukan kepada penonton (Mujiyanto \& Fuady 2014). Dalam naskah ini Putu Wjiaya menceritakan bagaimana permasalahan sosial yang sering terjadi dalam kehidupan masyarakat. Faktor ekonomi merupakan penyebab utama permaslahan-permasalahan sosial yang sering terjadi di masyarakat. Mulai dari kejahatan, moral, agama dll. Apabila faktor ekonomi di masyarakat tinggi, maka dapat menciptakan kehidupan masyarakat yang makmur serta kondusif. Namun jika faktor ekonomi masyarakat rendah maka akan memicu konflik di lingkungan masyarakat. Hal tersebutlah yang ingin disampaikan oleh Putu Wijaya melalui naskah drama ini.

Penelitian terhadap naskah drama H.A.H belum pernah dilakukan oleh penelitian manapun. Hal ini yang menjadikan peneliti tertarik untuk meneliti naskah drama ini. Meskipun begitu, beberapa penelitian terhadap naskah drama karya Putu Wijaya yang lainnya sudah banyak diteliti oleh peneliti lain. Misalnya penelitian terhadap naskah drama Bila Malam Bertambah Malam (BMBM) yang dilakukan oleh Prihantono (2018) melalui pendekatan Pascamodernisme. Hasil analisis terhadap naskah lakon karya Putu Wijaya memperlihatkan terjadinya pergeseran identitas budaya yang mencakupi pembaruan dan pengelabuan identitas budaya kelas sosial (sistem kasta) yang digambarkan melalui ideologi para tokoh. Hal tersebut digambarkan dengan percintaan lintas kasta antara Gusti Biang dan Wayan serta Nyoman dan Ngurah.

Penelitian ini jauh berbeda dengan penelitian yang dilakukan oleh Prihantono. Penelitian Prihantono mengkaji naskah drama BMBM dengan pendekatan pascamodernisme, sedangkan pada penelitian ini akan mengkaji naskah drama $H . A . H$ melalui pendekatan mimetic. Meskipun keduanya merupakan karya asli dari Putu Wijaya, namun dalam penelitian ini terdapat perbedaan objek, sekaligus perbedaan pendekatan karya sastra yang digunakan.Dengan pendekatan sosiologi sastra ini, diharapkan dapat menggambarkan bentuk realitas kehidupan yang tergambar dalam naskah drama tersebut. Sehingga, hasil dari penelitian ini nantinya juga dapat dijadikan badingan bahwa bukan hanya naskah drama BMBM yang menceritakan tentang keadaan realitas suatu masyarakat, namun naskah drama H.A.H juga mencerminkan realitas kehidupan suatu masyarakat.

Sastra dan masyarakat merupakan dua hal yang tidak dapat dipisahkan dan saling melengkapi. Sebagai cerminan dalam kehidupan masyarakat (Pujiharto 2012), karya sastra hadir sebagai bentuk pembelajaran ataupun memberikan model kehidupan bagi masyarakat. Hal tersebut merupakan salah satu fungsi sastra, dimana selain sebagai media hiburan bagi pembaca, melalui medium bahasa sebagai media utama dalam pengembangannya (Rokhmansyah 2014, 2-3), suatu karya sastra juga harus memberikan pengajaran kepada pembaca. Pembaca dituntun untuk menemukan nilai baik buruk yang terdapat dalam suatu karya sastra. Baik buruk kualitas suatu karya sastra, tergantung kepada pembaca yang memberikan interpretasi ataupun 
apresiasi kepadanya. Dengan adanya karya sastra mempermudah penyebaran aspek-aspek kemasyarakatan yang beragam serta menambah wawasan kepada pembaca.

Dalam memberikan apresiasi terhadap suatu karya sastra, peneliti bebas melakukan pendekatan terhadap karya sastra yang dikaji, asalkan karya sastra tersebut memiliki bukti-bukti yang kuat. Salah satukajian terhadap karya sastra yang dapat digunakan adalah pendekatan sosiologi sastra.Sosiologi sastra merupakan pendekatan pada karya sastra yang memahami hubungan antara karya sastra dengan realitas atau kenyataan kehidupan manusia (fakta kemanusiaan).

Sosiologi sastra merupakan salah satu pendekatan dalam karya sastra yang mengkaji hubungan suatu karya sastra dengan sosial masyarakat. Amriani (2014) menegaskan bahwa sosiologi sastra merupakan pendekatan dalam karya sastra yang tidak hanya mendeskripsikan fakta sosial masyarakat, namun di dalamnya juga terdapat tanggapan pengarang terhadap realitas atau fakta sosial tersebut. Sebagai ungkapan perasaan masyarakat, maka suatu karya sastra mencerminkan dan mengekspresikan hidup. Hal tersebutlah yang menjadikan adanya pendekatan sosiologi sastra. Irma (2018) mengatakan bahwa sosiologi sastra merupakan kajian pendekatan karya sastra yang mengkaji korelasi masyarakat dan karya sastra.

Sosiologi sastra beranggapan pada prinsip bahwa sastra bukan hanya produk imajiner penulis. Namun di dalamnya juga terdapat faktor-faktor sosial kemasyarakatan yang mempengaruhi terciptanya suatu karya sastra. Sosiologi sastra juga beranggapan bahwa karya sastra menyimpan informasi kemasyarakatan. Dengan demikian sosiologi sastra berupaya mencerminkan kehidupan masyarakat dalam bentuk tulisan sebagai alat perjuangan (Faruk 2015, 45). Dalam mencerminkan pengalaman yang dibuat dalam bentuk cerita tersebut, tentunya sedikit mengalami perombakan cerita yang sengaja dilakukan oleh pengarang. Hal ini tentunya bertujuan untuk menekankan daya estetik atau keindahan pada karya sastra

Karya sastra dapat dijadikan sebagai pembentuk struktur kehidupan masyarakat. Hal ini dikarenakan karya sastra menjadi produk sosial budaya, sehingga sastra dan sosiologi selalu hidup berdampingan. Sastra yang mencerminkan kehidupan tokoh-tokoh dapat dikatakan sebagai bentuk tindakan baik-buruk dalam kehidupan masyarakat. Adanya tindakan baikburuk tersebut memunculkan nilainilai kehidupan masyarakat yang bertujuan untuk mendidik pembaca (Endawarsana 2013b). Misalnya saja masyarakat pernah mendengar cerita pewayangan Petruk dadi ratu. Cerita tersebut merefleksikan kehidupan rakyat jelata yang berubah menjadi penguasa atau pemimpin.

Naskah drama sebagai suatu karya seni yang tidak hanya dinikmati dari bacaan, tetapi juga dapat dinikmati melalui seni peran yang menjadikan cerita karya Putu Wijaya ini semakin hidup. Kisah kehidupan dalam drama ditulis oleh sastrawan sesuai dengan cerminan atau realita kehidupan baik yang pernah ia alami, ia rasakan ataupun imajinasi pengarang. Melalui adegan-adegan yang sudah di tuliskan dalam naskah, penonton dapat menyaksikan dan menikmati pementasan sebuah drama dan merasakan bagaimana potret kehidupan yang terjadi dalam kehidupan masyarakat dalam naskah drama H.A.H. Hal tersebut juga tidak dapat terlepas dari keberhasilan para pelakon dalam membawakan perannya (Nuryani, Agus \& Dhika 2018). Pemeran-pemeran dalam pementasan suatu drama, memiliki peran untuk menyampaikan pesan-pesan yang 
menjadi tata krama yang berlaku dalam lingkungan masyarakat, dengan watak yang disesuaikan dengan kehidupan masyarakat (Endawarsana 2012).

Melalui pendekatan sosiologi sastra, penelitian ini akan mendeskripsikan bahwa naskah drama H.A.H karya Putu Wijaya ini menggambarkan realitas kehidupan tentang masalahmasalah sosial yang sering terjadi di masyarakat. Dengan membandingkan kutipan-kutipan dalam teks naskah drama dengan sumber-sumber dokumen lainnya yang mendukung, maka dapat dikatakan bahwa teks tersebut merupakan bentuk realitas kehidupan di masyarakat. Dari uraian tersebut maka penelitian ini bertujuan untuk mendeskripsikan realitas kehidupan masyarakat dalam naskah drama H.A.H karya Putu Wijaya. Penelitian dengan pendekatan mimetic pada karya sastra drama $H . A . H$ karya Putu Wijaya belum pernah diteliti oleh peneliti manapun, baik dengan pendekatan sosiologi sastra ataupun pendekatan yang lain. Untuk itu pemilihan naskah drama ini sebagai objek penelitian dikarenakan ingin menunjukkan bahwa naskah drama ini berisi gambaran realitas kehidupan masyarakat saat ini dan sering kita temui disetiap harinya.

\section{Metode Penelitian}

Metode penelitian dalam penelitian ini termasuk dalam penelitian deskriptif analitik. Metode analitik kerap mewarnai dalam penelitian karya sastra. Metode ini memaparkan data secara apa adanya dalam suatu karya sastra (Endawarsana 2013a). Sumber data dalam penelitian ini adalah kutipan dalam naskah drama H.A.H karya Putu Wijaya. Penelitian ini dilakukan melalui beberapa tahapan diantaranya: (1) pendekatan terhadap objek, (2) pengumpulan data, (3) analisis data, (4) sajian data. Dalam penelitian ini menggunakan pendekatan mimetic untuk menjawab penelitian ini. pendekatan mimetic berprinsip bahwa karya sastra merupakan bentuk tiruan kehidupan masyarakat. Teknik pengumpulan data dalam penelitian ini yaitu teknik dokumen. Adapun yang dilakukan yaitu membaca objek penelitian secara berulang-ulang agar dapat memahami makna dan menangkap isi dalam naskah drama yang dijadikan sebagai objek kajian. Setelah membaca data secara keseluruhan, prosedur selanjutnya adalah mencatat atau menandai kutipan dalam naskah drama yang mencerminkan realita kehidupan dalam masyarakat. Dalam penelitian ini menggunakan content analisys (analisis isi), yaitu dengan menguraikan isi yang terdapat dalam naskah dokumen. Teknik keabsahan data dalam penelitian ini yaitu dengan triangulasi sumber. Triangulasi sumber merupakan salah satu bentuk validitas data yang membandingkan data penelitian dengan suatu fenomena yang berkaitan (Moleong 2013). Dalam penelitian ini, peneliti melakukan observasi, atau pengamatan langsung tentang fenomena yang terjadi di masyarakat. Dengan memanfaatkan kasus-kasus yang serupa yang sudah terjadi dalam kehidupan masyarakat, dapat dijadikan sebagai penentu keabsahan data penelitian ini.

\section{REALITAS SOSIAL DALAM DRAMA H.A.H \\ Pergeseran Budaya}

Sepanjang hidup, manusia tidak dapat terlepas dari budaya. Budaya merupakan suatu tradisi atau adat istiadat yang sudah membudidaya di suatu daerah. Hal ini sudah turun temurun dan sudah hidup di masyarakat yang berasal dari nenek moyang. Budaya satu daerah dengan daerah yang lain adakalnya memiliki perbedaan namun adakalanya juga memiliki persamaan. Misalnya dalam naskah drama H.A.H. yang mengambil latar disuatu perkampungan di Indonesia, tentu budaya yang tercermin 
adalah saling menghormati, menghargai, gotong royong, dsb. Namun hal tersebut tidak tercemin dalam naskah ini. Dalam naskah ini seolah digambarkan bahwa masyarakat sudah individual dan jauh dari budaya yang semestinya. Perilaku yang di tampilkan dalam naskah tersebut tidak sesuai dengan kodrat manusia sebagai makhluk sosial, dimana mereka harus menjalin hidup bermasyarakat, lingkungan dan alam (Habibah 2018, 48). Hal tersebut dapat dilihat dalam kutipan berikut ini.

PINCANG : Bopeng!

PIAN : Aduh! Itu dia! (Mau lari)

PINCANG : Bangsat! Pengkhianat kamu! Bagi!

PIAN : Antara kita tidak ada apaapa lagi !

PINCANG : Siapa bilang ! Kita dari dulu cs, kamu jangan

PIAN : Siapa yang ngabur, gua cuma mabur angin-angin!

Pada kutipan di atas, digambarkan bahwa telah lunturnya rasa menghargai. Hal tersebut digambarkan melalui tokoh Bopeng yang sudah tidak mengenal Pincang. Padahal, Bopeng dan Pincang sudah lama saling mengenal. Mereka berdua adalah sahabat. Pincang sering menolong, ketika Bopeng mengalami kesulitan. Hal tersebut dibuktikan bahwa Pincang memberikan pekerjaan kepada Bopeng. Namun, ketika Bopeng sudah merasa bahwa dirinya kaya, sudah banyak uang setelah mendapatkan lotre 1 miliar, ia seolah lupa dengan apa yang sudah diberikan oleh Pincang kepadanya dulu. Sikap hidup yang ditampilkan oleh bopeng dan kepada pincang ini bukanlah merupakan bentuk sosial yang harus ditanamkan pada setiap diri individu yangmana mereka harus saling berbagi, memperhatikan, menyadari dan saling melengkapi satu sama lain (Sapendi 2015, 22). Perilaku yang tercermin dalam kutipan satu tersebut merupakan bentuk sikap degradasi moral yang tampak pada daerah perkampungan. Bukan hanya sikap Bopeng yang menjadi angkuh, namun sikap angkuh atau sombong juga ditunjukkan oleh tokoh Nenek dalam naskah drama ini.

NENEK : Ini banjir kiriman dari mana. Sampah dari mana ini. Ah?! Apa-apan ini Apaapaan ini!

PINCANG : Serbu saja, serbu !

Para pengemis mau mengambil barang-barang. Nenek mengusirnya. Para keluarga melihat para pengemis mengambil barang lalu ikut mengambil. Keadaan kacau. Keluarga Pian berusaha menghalangi.

Kedua kutipan tersebut di atas menggambarkan bagaimana bentuk pergeseran budaya yang terjadi dalam naskah drama H.A.H. Kedua kutipan diatas seoalah menggambarkan peribahasa kacang lupa kulit. Pada kutipan di atas menceritakan keserakahan, lunturnya rasa menghargai. Hal itu ditunjukkan dengan sikap nenek yang menganggap bahwa pengemis yang datang ke rumah Nenek adalah gembel murahan yang tidak pantas dekat-dekat dengannya. Sang nenek seolah lupa bahwa dahulu ia juga pernah hidup miskin sama seperti mereka. Fenomena yang tampak pada kedua kutipan di atas merupakan bentuk permasalahan sosial yang sering terjadi di lingkungan masyarakat. Budaya saling menghargai, menghormati mudah luntur hanya dengan memiliki materi atau kekayaan yang berlimaph

Baik kutipan satu maupun kutipan dua merupakan bentuk realita kehidupan masyarakat. Banyak dari masyarakat saat ini yang merasa sudah kaya, namun mereka sudah lupa bagaimana rasanya hidup susah sebelum mereka kaya. Mereka tidak pernah menengok kebelakang tentang masa lalunya dan tidak mau belajar darinya. Mereka telah merasa puas, hingga akhirnya setan mudah menggoda mereka dan terjadilah sikap ketamakan pada diri mereka. Begitulah 
amanat serta realitas yang tergambar dari kedua kutipan tersebut.

\section{Konflik Sosial}

Konflik sosial merupkan konflik yang terjadi antara satu kelompok dengan orang tertentu. Syam (2014, 115) berpendapat bahwa konflik sosial merupakan konflik yang sering terjadi di lingkungan masyarakat. Umumnya konflik sosial ini biasanya dipicu karena beberapa hal yang dapat menimbulkan kericuhan. Dalam naskah drama H.A.H ini konflik sosial digambarkan seperti pertikaian antara para tetangga dengan Warni. Hal tersebut dapat dilihat dalam kutipan berikut ini.

TETANGGA : Pokoknya kalau besok pagi duit kita belum dibalikin nggak tahu dah. Masuk masuk bui biarin, mau digampar juga nggak apa!

TETANGGA : Jangan pura-pura nggak denger lhu, brengsek!

Istri menangis tertahan sambil terus menyisir.

TETANGGA : Hhh kuno! Boleh mewek tapi hutang tetap hutang! Bayar!

TETANGGA : Jangan belagak pilon!

Pada kutipan di atas menggambarkan bagaimana bentuk konflik sosial antara para tetangga dengan Warni. Dalam kutipan tersebut menceritakan bahwa para tetangga sudah kuwalahan dalam mengahdapi sikap Warni. Tuntutan ekonomi yang mendesak menyebabkan kehidupan Warni bergantung dari para tetangga. Ia sering berhutang kepada tetangga untuk mencukupi kebutuhan seharihari. Namun lambat laun para tetangga muak dengan sikap Warni yang terusterusan hutang tanpa adanya kepastian kapan dia akan membayarnya. Maka dalam konflik diatas timbul karena perselisihan hutang yang belum juga dibayar. Para tetangga melabrak Warni dengan tujuan agar Warni merasa kapok sehingga hutang-hutang mereka segera di bayar dan dapat digunakan untuk kelangsungan hidup para tetangga.

Kutipan tersebut merupakan cerminan kehidupan masyarakat yang sering sekali kita temui. Misalnya pada tahun 2017, seseorang tega memukul tetangganya sendiri lantaran hutang yang tak kunjung dibayar. bahkan di tahun yang sama di daerah Jawa Barat terjadi pembunuhan hanya karena persoalan hutang. Beberapa kasus tersebut sebagai contoh bahwa masih sering terjadi tindak kejahatan hanya karena permaslahan hutang.Perbedaan yang tampak antara realita konflik sosial dengan yang berada dalam kutipan tersebut pada permasalahan hutang yang berujung pada konflik sosial. Sebagai manusia makhluk sosial, sudah sebaiknya kita saling menghargai, saling toleransi dan tolong menolong terhadap sesama, terutama kepada tetangga sebagai bentuk implementasi sila pancasila, dan agar dapat membentuk kehidupan masyarakat yang harmonis. Sesama tetangga harus saling hidup rukun, kompak agar tercipta kehidupan masyarakat yang harmonis.

\section{Degradasi Moral}

Moral merupakan perbuatan baik buruk manusia dalam kehidupan sehar-hari. Moral merupakan hasil produktivitas dari agama. Jika agama seseorang itu baik, maka baik pula moral seseorang. Hal ini juga menandakan apabila moral seseorang buruk maka buruk juga agamanya. Kemerosotan moral yang terjadi dalam naskah drama karya Putu Wijaya ini digambarkan bahwa masyarakat sudah tidak mematuhi norma-norma yang berlaku dalam kehidupan. Hal ini tergambar pada kutipan-kutipan berikut ini.

TETANGGA : Dia yang merusak anak kita yang lagi giatgiatnya belajar, kok orang yang tadinya bener diajakin main judi.

TETANGGA : Anak gue diajakin 
nyuntik. Diajakin main perempuan. kurangajar.

Pada kutipan di atas tersebut kemerosotan moral digambarkan oleh para tetangga yang geram terhadap ulah Warni yang mengajarkan anakanak tetangganya untuk berbuat judi, mesum dan main perempuan. Hal ini menendakan bahwa kehidupan masyarakat sudah jauh dari norma yang berlaku. Perbuatan judi, mesum dan main perempuan merupakan penyakit yang sering terjadi di masyarakat dan harus dihilangkan. Tidak seharusnya generasi penerus diajarkan dengan hal-hal yang bertentangan dengan etika dan moral yang berlaku di masyarakat tersebut. Hal ini lahbeberapa perilaku yang disampaikan oleh Ibda (2012, 338) bahwa krisis moral tengah menjamur di kalangan remaja, khususnya generasi penerus. Mereka telah lupa bahwa apa yang mereka lakukan sangat bertentangan dengan moral dan etika yang berlaku di masyarakat. Maka kutipan di atas merupakan bentuk pelanggaran moral yang terjadi di kalangan anak muda atau remaja. Dalam naskah drama ini kemerosotan moral juga ditunjukkan oleh sikap anak yang masih remaja, tetapi suka bermain (kencan) dengan lelaki yang sudah beristri.

ANAK : Ke mana saja mau.

HANSIP : Nanti kena marah orang rumah?

ANAK : Biarin. Udah biasa. (langsung naik ke boncengan). Ngebut ya! (memeluk). Ayo Oom!

HANSIP: Upahnya apa?

ANAK : Apa saja deh!

HANSIP : Tapi tiga kali!

ANAK : Sip.

Pada kutipan di atas tersebut menggambarkan perilaku kehidupan Lusi yang diam-diam menyukai Hansip yang sudah beristri. Sebagai orang yang beradab tidak semestinya Lusi menganggu hubungan orang lain, terlebih hubungan orang yang sudah berkeluarga. Hal itu tidak sesuai dengan norma pribadinya. SeharunyaLusi menghargai hubungan antara hasip dan istrinya dengan tidak menjadi orang ketiga didalamnya. Fenomena yang digambarkan oleh lusi dan hansip tersebut merupakan bentuk perilaku yang tidak beradab.

Perilaku yang tercermin baik dari kutipan satu dan kutipan dua di atas merupakan bentuk realitas kehidupan yang sering terjadi di masyarakat saat ini. Anak-anak atau generasi penerus sudah jauh dari etika dan tatakrama yang sudah berlaku dan membudidaya di masyarakat. Dalam dua kutipan yang sudah dijabarkan di atas menandakan bahwa bentuk degradasi moral anak-anak digambarkan dengan perbuatan seperti berjudi, main perempuan, menjadi pelakor. Hal ini sesuai dengan realitas kehidupan seperti saat ini, dimana anak-anak muda saat ini sudah banyak yang menyimpang dari moralitas. Pada tahun 2018, seorang perempuan di Jawa tertangkap berjudi hingga akhirnya di tangkap oleh polisi. Kemudian pada tahun yang sama juga beredar kabar seorang mahasiswa dan dosennya yang tertangkap saat razia. Hal ini sebagai bukti bahwa apa yang dituliskan oleh Putu Wijaya dalam naskah drama tersebut memang benarbenar terjadi di kehidupan masyarakat saat ini, meskipun naskah drama ini ditulis sudah berapa tahun lamanya.

Kerusakan moral atau degradasi moral sudah menjadi penyakit serius di kalangan remaja. Untuk itu, sebagai seorang remaja harus membentengi diri agar tidak mengalami hal yang serupa. Banyak cara yang dapat dilakukan oleh remaja dalam membentengi diri mereka. Salah satunya yaitu dengan mendekatakan diri kepada Agama. Semakin dekat dengan agama, maka semakin takut pula seseorang untuk berbuat perbuatan tercela. Semakin dekat pula dengan agama, maka moralitas individu akan semakin terbentuk sehingga menjadikan 
manusia yang lebih beradab.

\section{Kejahatan}

Kejahatan merupakan suatu kegiatan yang melanggar ketertiban, keamanan suatu aturan. Kejahatan sebisa mungkin harus dihindari karena dapat merugikan baik pelaku maupun korban. Pemahaman pengendalian kejahatan dan pencegahan kejahatan merupakan bagian dari lingkup pengendalian sosial (Aulina 2017, 8). Akan tetapi kejahatan merupakan suatu penyakit yang tidak bisa di hindarkan dalam kehidupan masyarakat. Misalnya seperti yang dicontohkan dalam naskah drama karya Putu Wijaya ini. Dalam naskah ini, di ceritakan bahwa tokoh Pincang merupakan pelaku kejahatan dalam masyarakat. Sifat keserakahan membawanya untuk sering meresahkan orang lain dan membawa petaka bagi orang lain. Hal tersebut dapat dilihat dalam kutipan berikut ini.

NENEK : Berisik!

PINCANG : Hee! Bongkok! Tikus busuk nggak usah ikut campur! Mau dipatahin lagi ya?

NENEK : Orang cuma ngasi tahu, seminggu bukan setahun Pian belum pulang.

PINCANG : Diam lhu! (mengokang senjatanya).

Ini senjata pinjaman. Yang punya lagi tiduran sama jande tukang tahu di pasar. Tapi kalau gua tembak, pale lhu pecah juga jadi seribu. Jangan ikut campur, Hantu!

Kutipan diatas menceritakan bagaimana bentuk kejahatan dan bagaimaan akibat dari kejahatan yang ditimbulkan oleh Pincang. Dalam naskah drama ini, Pincang digambarkan sebagai preman penguasa di gang mesum. Dalam kutipan diatas menceritakan bagaimana bentuk kejahatan yang dilakukan oleh Pincang. Demi mencari Bopeng, Pincang sampai masuk ke rumahnya dan membawa senjata tajam serta mengancam seluruh penduduk rumah agar segera memberi tahu keberadaan Bopeng. Hal tersebut membuat seisi rumah ketakutan. Akan tetapi seisi rumah tidak ada yang mengetahui keberadaan Bopeng, hingga akhirnya anaknya yang menjadi bencong dijadikan sebagai jaminan agar Bopeng mau menemui Pincang. Kejahatan yang dilakukan oleh pincang terus berlanjut hingga akhirnya, ketika ia bertemu dengan Pian (Bopeng), kejahatannya dapat dihentikan oleh sang Hansip yang bertanggung jawab sebagai keamanan lingkungan.

HANSIP : Tenang, tenang ! (Semua orang berhenti menyanyi).

PINCANG : Pian ! Bangsat ! Lhu jangan ngabur!

Hansip memukul Pincang.

HANSIP : Kapok!

Hansip memborgol Pincang. Pian keluar dari orang-orang itu.

PINCANG : Pian lhu jangan ngabur!

PIAN : Siapa bilang gua kabur.Gua ada di sini sekarang. Gua di sini!!

HANSIP : (Meniup sempritan sehingga semua diam)

Tidak punya uang susah, punya uang jadi begini akibatnya. Kirain gampang jadi orang kaya. Ayo bubar semua. Bubar, ini bukan urusan kita lagi ! Bubar ! Susah jadi juragan, tahu nggak, kalau nggak kuat ya kayak begini jadinya. Berabe nggak ?!

Karakter pantang menyerah demi mendapatkan apa yang diinginkannya. Begitulah karakter yang digambarkan oleh tokoh Pincang sebagai preman dalam naskah drama ini. Hal ini terlihat ketika pencarian Bopeng tidak membuahkan hasil, ia tidak pernah menyerah dan terus berusaha hingga akhirnya ia bertemu dengan Bopeng. 
Namun ternyata nasib tidak berpihak padanya. Ia justru ditangkap dan diborgol oleh Hansip agar tidak bisa berbuat onar lagi.Pada kutipan 2 di atas, menceritakan akibat dari perbuatan yang dilakukan oleh Pincang. Dalam kutipan tersebut digambarkan bahwa hasip berhasil mengamankan Pincang dengan memborgolnya agar tidak lagi berbuat onar, setelah Pincang bertemu dengan Bopeng dan berkelahi dengannya.

Baik dalam kutipan satu maupun kutipan dua tersebut menggambarkan bagaimana realita kehidupan di zaman sekarang ini. Di zaman milenial ini kejahatan banyak terjadi dimana-mana dan anak pun dijadikan sebagai jaminan agar sang penjahat berhasil mendapatkan apa yang diinginkannya. Tak hanya itu. Preman suatu daerah ataupun suatu wilayah masih berkuasa dan membuat resah masyarakat. Hal ini dapat dilihat pada tahun 2018, seorang preman ditangkap karena telah melakukan aksi criminal. Beberapa aksi criminal yang dilakukannya seperti pemalakan, penyerangan ruko, dan penguasaan wilayah. Hal ini menjadikan resah warga, hingga akhirnya ia pun ditangkap dan dipenjara. Kasus penangkapan preman tersebut sebagai bukti bahwa masih terdapat kejahatan preman yang terjadi saat ini. preman sangat berkuasa dan ingin menang sendiri. Mereka seakan tidak memiliki hati nurani. Begitulah yang tergambar dari tokoh Pincang. Dalam cerita ini juga ditampilkan bagaimana bentuk pemalakan yang dilakukan oleh Pincang dengan mengejar Bopeng. Namun pada akhirnya Pincang ditangkap oleh Hansip dan tidak mendapatkan hasil dari keinginannya.

\section{FAKTor PENYEBAB TERJAdinya Permasalahan Sosial}

Terjadinya permasalahan sosial yang terjadi di masyarakat seperti kejahatan, degradasi moral, pergeseran budaya dan konflik sosial yang terjadi di wilayah perkampungan seperti yang tergambar dalam naskah drama H.A.H karya Putu Wijaya ini, tidak terlepas dari faktor penyebabnya atau yang melatarbelakangi mengapa hal-hal tersebut dapat terjadi. Faktor-faktor penyebab ini saling bertalian sehingga menimbulkan realitas kehidupan seperti yang tercermin dalam penjabaran di atas. Adapun faktorfaktor tersebut seperti berikut ini.

\section{Kemiskinan}

Faktor ekonomi merupakan salah satu faktor yang mendukung keberhasilan dalam segala hal. Ekonomi yang maju akan mempermudah jalannya perkembangan manusia dalam segala hal. Bahkan sebaliknya, faktor ekonomi yang rendah akan menghambat perkembangan manusia dalam segala bidang. Sehingga kemiskinan dapat mempengaruhi segala aspek kehidupan masyarakat (Nugroho 2018, 249). Realitas kehidupan yang digambarkan dalam naskah drama H.A.H. karya Putu Wijaya ini menggambarkan bagaimana bentuk keluarga di suatu perkampungan yang miskin. Keadaan ekonomi yang mendesak untuk makan dan segala macam menuntut Warni untuk menghalalkan segara macam cara demi kelangsungan hidup keluarga. Hal itu dapat dilihat pada kutipan-kutipan berikut ini.

Pincang memeriksa setiap orang. Sampai ke anak perempuan, dia tibatiba merogoh tetek anak itu.

\section{ANAK : (Menjerit)}

PINCANG : Bangsat! Jangan purapura. Sama Hansip itu lhu kok mau diapa-apain! Ini senjata betulan tahu?! Gua udah sering bunuh orang!

ISTRI : Kasih saja! Kalau dia memang mau, asal bisa bayar!

Anak itu membuka bajunya, memperlihatkan bagian tubuhnya yang tadi dirogoh. Pincang meludah.

PINCANG: Bangsat, lhu pikir gua 
$\begin{array}{lr}\text { doyan daging } & \text { busuk? } \\ \text { Pincang } & \text { tidak } \\ \text { sembarangan } & \text { cari }\end{array}$ perempuan. Tahu. Paling nggak peragawati, cover girl atau pemain sinetron. Tutup lagi. Begitu kok dipamerin. Bau bacin, lhu! Mana, Boy?

Kutipan pada data di atas menggambarkan sosok Pincang yang tengah mencari keberadaan Bopeng (Pian). Mengetahui bahwa Bopeng berhasil menang dan mendapatkan lotre 1 milyar membuat Pincang tidak terima dan ingin mengambil sebagian dari hasil yang sudah didapatkan oleh Bopeng. Akan tetapi Bopeng terus saja menghindar dari kejaran Pincang. Alhasil yang menjadi imbas adalah keluarganya dimana anak dan istrinya selalu saja didatangi oleh Pincang.

Dalam kutipan diatas menggambarkan bahwa Pincang tengah mencari keberadaan Bopeng dengan memeriksa anak-anak Bopeng. Lusimenjerit ketika Bopeng melakukan perbuatan yang tidak senonoh padanya, ketika sedang memeriksa anak-anak Bopeng. Bukannya melakukan pembelaan terhadap anaknya, Warni justru malah menyuruh Lusi untuk memberikan barang berharga yang dimilikinya kepada Pincang asalkan Pincang mau membayar dan memberikan uang padanya.

Perbuatan yang dilakukan oleh Warni menyuruh anaknya tersebut dilakukan karena desakan ekonomi. Warni rela melakukan apa saja demi mendapatkan uang untuk kelangsungan hidup kedepannya. Salah satu yang dilakukan oleh Warni yaitu dengan menjual anaknya kepada orang lain asalkan dibayar. Menjual disini bukan dalam artian Lusi ikut dengan pian selamanya, namun dijual disini Lusi diberikan kepada Pincang untuk dinikmati. Dengan bayaran tersebut, Warni berharap uangnya bisa digunakan untuk kelangsungan hidup keluarganya untuk kedepannya. Tidak hanya menjual satu anak, namun warni juga mengizinkan anaknya untuk menjadi bencong.

NENEK : Kalau ada rezeki jangan lupa siapa yang kasih jalan dulu.

ANAK : Tak usah ya.

ISTRI : Cuci dulu sana, jorok!

ANAK : Ah capek ah! (Terus membanting tubuhnya ke tempat tidur)

NENEK : Anak baik-baik kok diajar nyabo.

ISTRI : Tapi ikut makan juga kan!

NENEK : Ajarin kek yang bener. Masak anak bagus-bagus begitu disuruh jadi

ANAK : Jadi apa? Bencong? Kalau ngak ada bencong ini juga nggak ada yang makan di sini. Jangan anggap remeh aku. Mesti, mesti bikin sakit hati. Maunya nyinggung perasaan. Kita udah capek bating tulang, terus saja dilipet kayak lumpia. Lamalama bunuh diri juga gua kebanyakan frustasi. Badan sudah ringsek begini, kasih kek penghargaan sedikit. Kok malah dihina terus. Memangnya ini comberan tempat berak? Tak usah ya! Kalau memang nggak butuh biar gua minggat sekarang biar tahu rasa! Biar kapok! (Meloncat bangun).

Tidak hanya menjual anaknya, Warni juga memperbolehkan anaknya menjadi bencong. Hal itu dapat dilihat pada kutipan dua. Dalam kutipan tersebut dijelaskan bahwa kehidupan Warni untuk makan bergantung pada hasil kerja anak laki-lakinya yang menjadi bencong. Hal tersebut diakui sendiri oleh anaknya, bahwa jika tidak ada dia maka satu keluarga tidak ada yang merasakan makan. Rendahnya ekonomi yang dialami oleh keluarga Warni menuntunnya agar bisa 
menghalalkan segala macam cara demi kelangsungan hidup. Ia tidak peduli dan juga tidak memikirkan apakah uang yang mereka dapat dihasilkan dari perbuatan yang baik ataupun buruk. Baginya, uang adalah segalanya. Uang adalah penggerak agar ia bisa merasakan kenikmatan dan kelangsungan hidup.

Dari dua kutipan di atas, menggambarkan bahwa rendahnya ekonomi suatu masyarakat menjadi penyebab kejahatan, dan degradasi moral terjadi. Misalnya seperti yang dilakukan oleh pincang. Kesehariannya yang tidak bekerja sehingga tidak mendapatkan pemasukkan ekonomi membuatnya nekat melakukan kejahatan yang ditunjukkan dengan mengancam dan menggeledah seluruh isi rumah Bopeng. Selain itu rendahnya ekonomi suatu masyarakat juga berdampak pada moral anak-anak seperti yang ditunjukkan pada kutipan dua. Demi mendapatkan uang untuk kelangsungan hidup, anak-anak warni nekad melakukan perbuatan yang tidak senonoh. Salah satunya dengan menjadi bencong di perempatan. Dengan menjualkan dirinya kepada laki-laki hidung belang, si bencong berharap dapat mendapatkan uang dan dapat membantu kelangsungan hidup keluarga.

Dari hal ini sudah tampak jelas bahwa faktor ekonomi menjadi salah satu penyebab terjadinya kejahatan dan degradasi moral dikalangan masyarakat. Mereka melakukan segala macam cara demi mendapatkan uang agar bisa melanjutkan kehidupan mereka. Bagi mereka, kelangsungan hidup adalah harga mahal dan nomor utama yang harus dipenuhi, daripada mereka harus mati kelaparan. Mereka tidak memperdulikan segala macam cara yang dilakukan apakah baik ataupun buruk.

\section{Agama}

Agama merupakan pedoman hidup bagi manusia. agama adalah keyakinan dan kepercayaan yang harus dianut oleh umatnya. Agama merupakan seperangkat aturan yang mengatur kehidupan manusia agar lebih menjadi pribadi yang baik. Dalam agama selalu mengajarkan kepada manusia untuk berbuat baik dan mencegah yang buruk (amal ma'ruf nahi mungkar). Jika seseorang memiliki iman yang baik maka dia tidak akan mudah tergoda nafsu setan atau melakukan perbuatan tercela. Dalam naskah drama karya Putu Wijaya ini menggambarkan realita kehidupan masyarakat yang jauh dari norma agama. Kemerosotan iman terjadi ketika Warni brniat untuk bunuh diri, Bopeng yang suka mabukmabukkan, boy yang suka mengumbar alat kelaminnya untuk perempuanperempuan, dll. Hal itu dapat dilihat dari beberapa kutipan berikut ini.

Kutipan 1

ISTRI : (Berbalik. Semua anak-anak berhenti tertawa dan tidur lagi). Tutup mata kamu, besok semua harus kerja. Nggak ada beras lagi. Bapak kamu sudah setahun kabur.

NENEK : (Dari luar). Sebulan.

ISTRI : Besok semua kerja kalau mau makan! Sabet apa saja. Belajar sama pemimpinpemimpin kitya itu. Wakilwakil rakyat Sudah kenyang mereka masih ngerampok orang miskin. Jangan main melulu. Di Pasar Burung, di perempatan, banyak orang lengfah yang bisa diembat, asal lhu berani aja, jangan takut. Jangan cuma berani sama tetangga, paling banter kamu cuma kebagian jemuran, di loak juga percuma, ngabis-ngabisin tenaga saja. Kalau nyolong jangan tanggung. Seratus trilyun. Masuk bus kek cari dompet. Ngompas toke-toke. Atau cari anjing di kompleks perumahan orang kaya. 
Lama-lama nanti ada pengalaman dikit, ntar baru nyolong anak, besar tadahannya sekarang. Kita bisa beli rumah di Pondok Indah. Daripada nyabo, badan capek, modal nggak balik, akhirnya penyakitan. Terus begini lama-lama kita mati.

Istri duduk kembali. Nyisir. Nenek masuk membawa sesuatu yang disembunyikannya.

Kutipan di atas menggambarkan bentuk kemerosotan akidah di masyarakat. Dalam kutipan satu menggambarkan bagaimana kehidpan krisis ekonomi yang dialami oleh keluarga warni, sehingga ia menyuruh anak-anaknya untuk bekerja dengan menghalalkan bebagai macam cara. Misalnya saja dalam kutipan tersebut dijelaskan bahwa warni menyuruh anak-anaknya untuk merampas, mencuri, ataupun mencopet barangbarang yang dapat menghasilkan uang, sehingga dapat digunakan untuk kelangsungan hidup keluarga. Kebebasan yang diberikan Warni pada anak-anaknya juga tergambar pada perilaku lusi yang suka menggoda Hansip, hingga membuat Istri Hansip geram.

ISTRI HANSIP : Lonte! Kecil-kecil sudah gatal begini, besarbesar kamu jadi peyeum! Setan!

Meludahi. Anak lari dan meloncat masuk ke bawah balai-balai.

ISTRI HANSIP : Bilangin Mak kamu, kalau mau merebut laki orang terang-terangan! Kita selesaikan secara jantan!

Meludah lagi.

HANSIP : Dia Cuma mau num... Langsung dihajar lagi.

ISTRI HANSIP : Pulang! Cepat pulang! Dasar lelaki, bisa saja cari alasan. Dinas kek, lembur kek, tahunya cuma mau nyuci barang. Sudah layu begitu masih saja bertingkah! Minggat! (Hansip mendorong motornya dengan gugup)

Belum kapok kamu ya! Satu kali lagi coba-coba ganggu laki gua awas barang kamu tak robek sampai jebol! Kalau ada modal sih mendingan. Ini udah gembrot (maksudnya memaki, ternyata ia menyebutkan ciri-ciri phisik dirinya sendiri), beser, bau, kok genitnya minta ampun!

Tetangga muncul lagi.

Anak adalah titipan yang harus dijaga oleh orang tua. Keberhasilan anak dalam mendidik anak tergantung pada pola asuh yang diberikan oleh orang tua. Pada kutipan di atas menggambarkan bahwa lemahnya akidah yang diajarkan pada orang tua pada anak berdampak pada kelakuan akhlak yang kurang baik di masyarakat. Hal itu digambarkan dengan sosok hansip yang mencintai lusi. Padahal hansip sendiri sudah berkeluarga dan memiliki anak yang dijodohkan dengan boy. Pada subbab sebelumnya telah disampaikan bahwa perbuatan Lusi tersebut merupakan bentuk kemerosotan moral dan tidak seharusnya membuat Lusi berbuat demikian.

Lemahnya akidah di masyarakat yang tergambar dalam naskah drama H.A.H karya Putu Wijaya ini menjadi salah satu penyebab adanya realitas kehidupan sosial yang membuat kemerosotan akhlak. Adanya keserakahan warni yang menuntut anaknya mencari uang dengan menghalalkan berbagai macam cara seperti mencopet, mencuri, dan merampok ini mengakibatkan timbulnya kejahatan di masyarakat. 
Kelakuan Hansip yang masih suka dengan perempuan lain juga mengakibatkan timbulnya konflik sosial antara warni dan istri hansip. Seandainya iman dan akidah mereka kuat, tentu saja hal yang demikian tidak akan pernah terjadi di suatu masyarakat. Dari hal ini sehingga dapat diketahui bahwa kurangnya iman dan akidah agama juga dapat memincu timbulnya kejatahatan dan konflik sosial di masyarakat.

\section{Pendidikan}

Pendidikan merupakan salah satu usaha sadar dan terrencana untuk membentuk ranah kognitif (pengetahuan) siswa dan juga karakter siswa. Pendidikan merupakan suatu proses untuk mendidik siswa agar lebih baik dan menjadi manusia beradab, demi kemajuan bangsa. Melalui pendidikan yang baik, akan menciptakan generasi penerus yang baik pula. Dengan berjalannya pendidikan maka usaha bangsa Indonesia untuk mencerdaskan kehidupan bangsa akan dapat terealisasikan. Namun hal tersebut tidak tercermin dalam naskah drama H.A.H karya Putu Wijaya ini. dalam naskah drama ini digambarkan dengan kualitas pendidikan masyarakat yang rendah, sehingga menciptakan anak yang jauhdari etika. Hal tersebut dapat dilihat dalam kutipan berikut ini.

ISTRI HANSIP : Bener, kalau tidak
kasihan, sudah lama
tak gasak.Tahu kan?
Bukan hanya anak
perempuannya, yang
laki-laki juga sudah
rusak semua. Masak
dari kecil bukannya di
sekolahin begitu, biar
tidak rusak seperti
bapaknya. Malah
diajarin nyolong.
: (Nyeletuk) Habis
kalau sekolah
memangnya bisa cari
makan?
ISTRI
: Orang sekolah bukan

untuk cari makan tapi cari kepintaran supaya tidak ngaco, bego!

ISTRI : Buat apa pintar kalau kalau akhirnya nyolong juga? Lebih baik langsung saja nyolong.

ISTRI HANSIP : Dengar. Dengar tidak? Sadar dia. Sadar dia bejat. Itu suara setan!

ISTRI :Daripada mati kelaparan lebih baik bejat.

TetAngGa :Gila ! Kalau sudah begini harus depetrus juga biar jangan jadi penyakit.

ISTRI HANSIP : Lho, jadi kamu sadar kamu mendidik anak kamu jadi lonte, jadi maling? Sadar ya!

ISTRI :Habis mau jadi apa lagi?

ISTRI HANSIP :Tuh dengar, dia sadar! TETANGGA :Tidak bisa diajak berunding lagi kalau sudah begini. Sudah nekat! Sikat saja!

ISTRI

:Anak banyak begini bagaimana kasi makan kalau tidak maling? Bantingtulang sudah bosan, nggak ada hasilnya.

Kutipan di atas sebagai bukti bahwa pendidikan sangat penting untuk memebentuk akhlak serta moral bagi anak. Dalam kutipan tersebut menggambarkan bagaimana bentuk kemerosotan moral yang diakibatkan karena kurangnya pendidikan bagi anak. Dalam kutipan tersebut digambarkan bahwa Warni tidak pernah menyekolahkan anak-anaknya. Hal ini karena banyaknya anak dan banyaknya beban pengeluaran hidup yang harus dikeluarkan membuat Warni tidak menyekolahkan anaknya. Sehingga dampak yang 
terjadi adalah anak menjadi "rusak". Kerusakan anak-anak Warni di dalam naskah tersebut digambarkan seperti suka mencuri, menjadi pelakor, menjadi bencong dan suka menggoda dan menyebarkan penyakit kelamin.

\section{KESIMPULAN}

Karya sastra merupakan cerminan kehidupan yang terjadi dalam masyarakat.. Naskah drama sebagai salah satu jenis karya sastra yang dapat dinikmati tidak hanya melalui tulisan tapi juga seni peran juga menggambarkan kehidupan masyarakat. Berdasarkan hasil analisis yang telah dipaparkan tersebut diatas, maka dapat disimpulkan bahwa lakon naskah drama H.A.H Karya Putu Wijaya menggambarkan realitas sosial kehidupan di masyarakat.

Penggambaran realitas sosial kehidupan perkampungan yang terdapat dalam naskah drama tersebut mencerminkan permasalahan sosial yang sering terjadi di masyarakat saat ini yang meliputi kejahatan, degradasi moral, pergeseran budaya dan konflik sosial. Hal ini disebabkan karena keadaan lemahnya ekonomi, kurangnya pemahaman terhadap ajaran agama tentang akidah, iman dan takwa, dan kurangnya pendidikan. Melalui pendekatan sosiologi pada naskah drama tersebut, peneliti dapat menyimpulkan bahwa faktor utama yang melatar belakangi adanya gejalagejala sosial di masyarakat adalah lemahnya ekonomi. Lemahnya ekonomi yang terjadi di kehidupan berdampak pada segala aspek yang menimbulkan berbagai masalah seperti kejahatan, kemerosotan moral dan konflik dapat terjadi di masyarakat, meskipun faktorfaktor yang lain juga menjadi faktor penyebab.

Dari uraian tersebut juga dapat disimpulkan bahwa Putu Wijaya menuliskan naskah drama ini dengan tujuan memberikan gambaran kepada masyarakat terkait fenomena kehidupan yang terjadi saat ini. Ekonomi berperan penting dalam pembangunan masyarakat. Dengan ekonomi yang baik maka akan menciptakan kehidupan masyarakat yang tentram dan damai. Namun sebaliknya kehidupan dengan ekonim yang rendah akan membuat permasalahan-permasalahan yang datang silih berganti.

\section{DAfTAR Pustaka}

Amriani, H. 2014. "Realitas Sosial Dalam Novel Ronggeng Dukuh Paruk Karya Ahmad Tohari". Sawerigading, 20 (1), 99-108

Aulina, A. 2017. "Kejahatan di Wilayah Perkotaan dan Model Integratif Pencegahan Kejahatan". Jurnal Ilmu Kepolisian, 11 (3): 6-15

Endawarsana, S. 2012. Teori Pengkajian Sosiologi Sastra. Yogyakarta: UNY Press

Endawarsana, S. 2013a. Metodologi Kritik Sastra. Yogyakarta: Penerbit Ombak

Endawarsana, S. 2013b. Sosiologi Sastra: Studi, Teori, dan Interpretasi. Yogyakarta: Penerbit Ombak

Faruk. 2015. Pengantar Sosiologi Sastra: dari Strukturalisme Genetik sampai Post-Modernisme. Yogyakarta: Pustaka Pelajar

Habibah, S. 2018. "Filsafat Pendidikan Islam dan Tameng Moralitas Bangsa". Ta'lim : Jurnal Studi Pendidikan Islam, 1(1): $40-58$

Ibda, F. 2012. "Pendidikan Moral Anak Melalui Pengajaran Bidang Studi PPKN dan Pendidikan Agama". Didaktika 12 (2): 338-347

Irma, CN. 2018. "Nilai-Nilai Pendidikan Karakter Dalam Novel Ibuk Karya Iwan Setyawan". Retorika, 11 (1): 14-22. https://doi.org/10.26858/retorika.v11i1.4 888

Moleong, LJ. 2013. Metodologi Penelitian Kualitatif Edisi Revisi. Bandung: PT Remaja Rosdakarya

Mujiyanto, Y \& A. Fuady. 2014. Kitab Sejarah Sastra Indonesia. Yogyakarta: Penerbit Ombak

Nugroho, YD. 2018. "Penerapan Regresi Logistik Hierarki Biner Untuk 
Menentukan Determinan Kemiskinan Di Bengkulu Dengan Menggunakan Indeks Aksesibiltas Sarana Umum (IASU) Sebagai Variabel Kontekstual". dalam Pendidikan Matematika Universitas Muhammadiyah Purworejo - Ruang Seminar UMP: 249-261

Nuryani, L, BS Agus, \& P Dhika. 2018. "Variasi Bahasa Pada Pementasan Drama Cipoa dan Sidang Para Setan Mahasiswa Pendidikan Bahasa dan Sastra Indonesia Tahun 2017". Widyabastra, 6 (1): $62-75$

Prihantono, KD. 2018. "Pergeseran Identitas Budaya Dalam Naskah Lakon Putu Wijaya Bila Malam Bertambah Malam: Kajian Pascamodernisme". Alayasastra, 14 (1): 39-52
Pujiharto. 2012. Pengantar Teori Fiksi. Yogyakarta: Penerbit Ombak

Rokhmansyah, A. 2014. Studi dan Pengkajian Sastra: Perkenalan Awal Terhadap Ilmu Sastra. Yogyakarta: Graha Ilmu

Sapendi. 2015. "Internalisasi Nilai-Nilai Moral Agama Pada Anak Usia Dini". At Turats, 9 (2):17-35

Syam, NK. 2014. "Kearifan Dakwah dan Konflik Sosial". dalam Prosiding Seminar Nasional Penelitian dan PKM Sosial, Ekonomi dan Humaniora: 115120) 
154 Leksema Vol 4 No 2 Juli-Desember 2019 